\title{
THE DEPARTMENT OF SCIENTIFIC AND INDUSTRIAL RESEARCH
}

\section{TWENTY-FIFTH ANNIVERSARY}

W HEN Mr. J. A. Pease, the then president of the Board of Education, in introducing the Board of Education estimates in the House of Commons on May 13, 1915, announced the impending appointment of an Advisory Council for industrial research in Great Britain, to be specially entrusted with the supervision and encouragement of scientific research particularly in relation to industry, he laid special stress on the importance of providing for the training of the scientific and technical personnel. Already the early months of the War of 1914-18 had revealed the dangers and difficulties in which Great Britain was placed through the neglect of science by industry and the absence of an adequate scientific personnel. We had not merely to make the best use of the scientific men we then possessed, but also to provide a further supply in the future. The debates in the House of Commons on the proposals eventually issued by Mr. Pease's successor at the Board of Education, Mr. Arthur Henderson, in a White Paper (Cmd. 8005 ), as in the original statement, thoroughly endorsed the Government's proposal to deal with this problem as an integral part of a comprehensive improvement in our educational system. It was indeed originally proposed that the whole scheme should be supervised by the Board of Education, to which the expenditure of $£ 1,000,000$ over a period of five years would be entrusted on the advice of the proposed Central Council of Commercial and Industrial Research.

The reports of these debates reveal after twentyfive years the immense debt of the nation to those whose vision and courage launched this venture even in the days of war. That the outbreak of war in September of last year found Great Britain with resources in scientific and technical personnel adequate to meet all demands is due in no small measure to the foresight and energy of such men as Lord Haldane, Lord Balfour and Dr. Addison, and the wise guidance of such successive chairmen of the Advisory Council as Sir William MeCormick and Lord Rutherford. Whatever concern may have been expressed as to the use which is being made of available scientific personnel or resources, except perhaps in a few fields such as those of the social sciences, the ability of the scientific workers and the research organization of the country to meet whatever demands may be made upon them by the War is beyond question. Even before the War of 1914-18, scientific workers in Great
Britain, if few in number compared with those of some other countries, had many outstanding achievements to their credit and were playing their full part in scientific advance. For the great advance in the numbers of British workers, and unprecedented expansion in the application of scientific research in industry and in every phase of national life in the last quarter of a century, without any impairment of that capacity, no small share of the credit must be given to the Advisory Council of Scientific and Industrial Research, first established by Order in Council on July 28,1915 .

The White Paper which outlined the scheme alluded to the difficulties in which many of our industries had been placed in 1914-15 through our inability to produce at home certain articles and materials required in trade processes, the manufacture of which had become localized abroad, because science had there been applied more thoroughly and effectively to the solution of scientific problems bearing on trade and industry and to the elaboration of economical and improved processes of manufacture. To advance or even maintain our industrial position it was essential to aim at such a development of scientific and industrial research as would place us in a position to expand and strengthen our industries and to compete successfully with the most highly organized of our rivals. The scheme was designed to establish a permanent Department for the promotion of industrial and scientific research.

For this purpose a Committee of the Privy Council was set up, responsible for the expenditure of any new moneys provided by Parliament for scientific and industrial research, and an Advisory Council, responsible to the Committee of Council, and composed mainly of eminent scientific men engaged in industries dependent on scientific research. The prime functions of the Advisory Council were and are to advise the Committee of Council on proposals for instituting specific researches, or for establishing or developing special institutions or departments of existing institutions, for the scientific study of problems affecting particular industries and trades, and on the establishment or award of research scholarships or fellowships. The Advisory Council is also available to advise the education departments as to the steps which should be taken for increasing the supply of workers competent to undertake scientific research. 
The Advisory Council, which met for the first time on August 17, 1915, was further directed to frame a programme for its own guidance in recommending proposals for research and for the guidance for the Committee in Council in allocating such State funds as might be available, designed in advance to operate over some years, having regard to the relative urgency of the problems requiring solution, the supply of trained investigators available, and facilities in laboratories or equipment which could be provided. The method of approach adopted by the Council is indicated in its first report. The Council was under no misapprehension as to the relation between pure and applied science. It was decided to give science in its application to industry precedence over pure science in the Council's deliberations, and after a period of careful inquiry and consultation to initiate a gradual and systematic attack upon a wide and carefully selected front.

The soundness of the policy and principles outlined in the first report of the Advisory Council is attested by the results which have followed from these modest beginnings. Realizing from the start the dependence of the success of its work upon a greatly increased supply of research workers and upon a hearty spirit of co-operation among all concerned, whether scientific workers, business men, professional and scientific societies, universities and technical colleges, local authorities and Government departments, it was recognized also that neither condition would be effective alone. The first condition of success was at the start unattainable, and even at the end of the War of 1914-18 the number of trained research workers was insufficient for the demand. Effective research, particularly in its industrial application, calls increasingly for the support and impetus that come from the systematic team-work of investigators of mediocre ability, working intelligently under the direction of first-class leaders.

The problem of the supply of investigators of the requisite abilities in sufficient number is largely a matter for the education departments. It is not entirely a matter of the provision of scholarships, but depends also on the standard of students entering the universities. None the less, in the first ten years, as the report of the Advisory Council for the year 1925-26 shows, much was done to re-establish a body of scientific workers of the highest rank for purely scientific work, and to enable men who intended to make some branch of industry their profession to equip themselves for scientific work in industry by postgraduate research work.

Of the seven hundred allowances given in the first seven years, nearly four hundred were to students of chemistry, and in its report the
Advisory Council expressed the opinion that too many men were encouraged to specialize in chemistry. The records of the Department showed that large numbers of applications were received whenever a post for chemical research was advertised, while the demand for men who combined a study of chemistry with other subjects such as agriculture, biochemistry or botany outstripped the supply. There was also a scarcity of men interested in, and capable of, the application of general physics in industry, a position which has hardly been improved in the subsequent fifteen years, as the experience of the Central Register indicates. Although the proportion of grants held by students in training in biology has steadily increased in recent years, and has for some years been equal to or greater than those held by students in physics, students of chemistry have consistently been at least twice as numerous as those of students in any other branch of science in receipt of grants.

The service which the Department of Scientific and Industrial Research has rendered to the development of pure science is far from being limited to the provision of maintenance allowances for students or even special assistance to independent research workers, whether by helping young research workers of exceptional ability to pursue their work for a limited period without the necessity of finding other employment, by the provision of funds for research or technical assistants or the purchase of special apparatus and equipment, or, in special circumstances, by making really substantial grants. The Advisory Council has consistently shown in its reports a wise concern for the conditions of employment of the research worker, whether in regard to salary or security of tenure ; this is a contribution to the raising of standards in the last two decades which has earned the cordial appreciation of all scientific workers.

In regard to the actual prosecution of research, the record of the twenty-five years work of the Department makes impressive reading. It includes the development and expansion of such institutions as the National Physical Laboratory and the Geological Survey and Museum of Practical Geology, which were already in existence and were taken over by the Department. It includes the establishment of the Fuel Research Station at Greenwich, the Building Research Station at Watford, the laboratories of the Food Investigation Board at Cambridge, East Malling, Chipping Campden and Torry, the Forest Products Research Laboratory at Princes Risborough, the Radio Research Station at Slough, the Chemical Research Laboratory at Teddington, and the Road Research Station at Harmondsworth. 
At these stations and under the direction of the various boards or committees of the Department, research has been initiated on a national scale into such fields as fuels, forest products, food, water pollution, transport problems. Simultaneously, through the co-ordinating boards set up in 1920 , the research departments of the Fighting Services have not only been placed on a secure footing but also brought into effective contact with the work of the Department. Medical research and agricultural research have also expanded considerably in the period, often in co-operation with the work of the Department, while in 1925 there was formed the Committee of Civil Research to advise on broad questions of national policy involving scientific and industrial research on much the same lines as the Committee of Imperial Defence.

Besides all this co-ordination of existing organizations and initiation of fresh lines of work, the Department has done much to stimulate research on questions of interest to the Dominions and Colonies, and to secure co-ordination with the corresponding departments formed overseas, such as the Council for Scientific and Industrial Besearch of the Commonwealth of Australia, the Department of Scientific and Industrial Research of New Zealand, or the National Research Council of Canada, notably in investigations on food problems or such matters as Empire timber. In such imperial problems and in the more domestic problems of Great Britain, the Department has succeeded in promoting co-operation between the different interests concerned, whether consumers, manufacturers, Government departments or others in the attack on common problems.

To the extent of that co-operation the development of the research association movement in Great Britain bears emphatic witness. On December 1, 1916, in receiving a deputation of the Board of Scientific Societies, Lord Crewe, as Lord President of the Council, announced the intention of the Government to ask Parliament to place a million pounds at the disposal of the Department to enable it to co-operate with the industries of the country in the foundation and maintenance of approved associations for research during the following five years or more. This fund was duly voted by Parliament and became available in July 1917 ; the scheme had been outlined in detail in a paper issued by the Department in June 1917. The scheme visualized the systematic development of research and the co-operation of science with industry carried out under the direct control of the industries themselves. In this way it was hoped to avoid the danger that, if the work wero done by the State or the universities, the results would not be put into immediate operation, and as they would necessarily be published, might become of equal or greater benefit to foreign competitors. Moreover, it was hoped that co-operation of the firms engaged in any one industry might enable research work to be undertaken which could not have been dealt with by a single firm.

The rapid progress made under the scheme was indicated in the excellent account issued in 1927 under the title "Co-operative Industrial Research", and when on the exhaustion of the Million Fund the Advisory Council devoted the greater part of its annual report for the year 1932-33 to a review of the scheme, it was able to point to important practical achievements as well as to evidence that the scheme had contributed to a definite acceleration in the advance of industrial science. The first four associations were licensed by the Board of Trade under the scheme in 1918, followed by ten more in 1917, nine in 1920 and one each in 1921, 1923, 1930, 1937 and 1938 ; two more were formed in 1926, as well as similar organizations in 1929 and 1931, though not of the same formal and legal status, by the National Federation of Iron and Steel Manufacturers and the Institution of Automobile Engineers.

Certain of the associations never became effective, and some after several years active work ceased to operate or became merged in other bodies fulfilling similar functions. The last report of the Department shows, however, that there are still twenty-two research associations in existence, serving a very wide range of industries, and achievements to their credit already offset very largely the expenses of their work. For example, it has been computed that, in the first ten years of its work, the researches of the Electrical Research Association on insulating oils, costing $£ 8,500$, had involved savings to the industry of at least $£ 100,000$ a year. Further researches on buried cables, costing $£ 18,000$, had represented a saving to the industry of at least $£ 250,000$ per annum and added four millions to the value of the existing cables. Investigations of the British Cast Iron Research Association, if fully adopted, would result in the saving of fuel and other economies of $£ 200,000$ per annum. Almost equally striking savings have resulted from investigations conducted by the Non-Ferrous Metals Research Association on ternary lead alloys used in sheathing cables and for water-pipe service, and by the Refractories Research Association on prolonging the life of saggars.

The significance of such achievements in the present urgent need for national economy in every sphere is obvious, but too much stress should not bo laid on such concrete examples. Often it is difficult to assess at all accurately either the direct or the indirect results of such research in stimulating a scientific approach to industrial problems 
and the application of scientific knowledge in industry. The Advisory Council has from the start been alive to the importance of securing not merely the initiation of industrial or scientific research but also the utilization of its results by industry. "One of our most important tasks", wrote Lord Rutherford in the 1935-36 report, "is so to organize the conduct of research as to promote contact with industry", and this is one of the main reasons for attaching so much importance to the development of the research association movement. The application and development of scientific ideas in industry depend upon a complete understanding of the way in which industry can make use of science and scientific method.

So far back as its 1930-31 report, the Advisory Council noted the extent to which the time of the staff of a research association was occupied in work for the firms which constitute it and in visits to works, thus functioning as the 'general staff' of the industry; further, increasing attention has been given to the presentation of the industrial and financial implications of scientific data in publications so as to facilitate their utilization on a wide scale in industry.

However admirable the results achieved by many of the research associations, the movement has been open to criticism on account of the inadequate scale on which it has been financed. Moreover, the success which has attended the scheme of block grants which was initiated as a result of a review of the situation during 1933-34 and later discussions with the various associations should not lead us to overlook the fact that, although the total sum subscribed by industry has increased by forty per cent to more than a quarter of a million pounds per annum since the scheme came into operation, there are still associations receiving insufficient financial support from the industry to qualify for the block grant.

Important as the research association movement may be, it provides only one example of the way in which the work of the Department has led to increasing value being placed upon research by the leaders of industry. An admirable example of the way in which progress has been made in gaining the confidence of industry is provided by the work of the Water Pollution Research Board, the youngest of the major research activities of the Department, notably in relation to the disposal first of polluting waste waters from the beet sugar industry and later in the treatment and disposal of effluent from dairies and the manufacture of milk products. The developments referred to in the last report of the Advisory Council in relation to the testing of electrical switchgear by the National Physical Laboratory provide a further example of this tendency, while equally striking illustrations might be found in such fields as the testing or specification of building elements for their resistance to fire, or the work of the Building Research Station or Steel Structures Research Committee in co-operation with various branches of industry. The importance of the work of the Building Research Board of the Department in securing the most economical use of all building materials in war-time need scarcely be further stressed, whether in view of the magnitude of the Government's building programme alone, which for 1940 is estimated to cost about $£ 200,000,000$, chiefly for aerodromes, storage depots, and factories, or with regard to the necessity for conserving to the utmost our resources of steel and timber and reducing imports. Dr. E. V. Appleton, the present secretary to the Department, recently indicated that adoption of the Board's recommendations would permit substantial economies in timber and steel, and special arrangements have been made by the Government for dealing with the technical problems of building created by the War.

The research work which the Department itself has developed in the national interest has in general been that required to deal with such primary needs of man as his food, fuel, building, the use of timber and the protection of his drinking water or the atmosphere from pollution. The impressive review given in last year's report of the Advisory Council of the twenty years work of the Food Investigation Board shows how important are the advances which have flowed from work initiated in 1917 in face of the serious shortage of food then existing. It is difficult indeed to assess the importance to our war effort of the increased knowledge gained in regard to the storage and transport of food of all classes. Victory might indeed turn on the elimination of waste in this manner by the preservation of existing stores or supplies from damage by disease or pests, but it may equally depend on the further increase in our resources coming from more effective utilization, through the Department, of the resources and knowledge already available for the elaboration and execution of a sound policy of food production and supply.

Great as have been the achievements of the Department and admirable the work of its numerous research stations, boards or sections, the nation cannot rest content with what has already been done. There are still industries which suffer from the absence of scientific direction and failure either to prosecute research or utilize existing scientific knowledge. Five years ago, the Advisory Council wrote in its report: "The scientific outlook of these industries leaves much to be desired. Neither in the directorates nor among the technical and executive staffs is sufficient weight yet given to scientific attainment and experience, and until 
a radical change has taken place in this respect the position is bound to be that the industries as a whole will remain unable to obtain the full benefit of the results of scientific investigation." The scale upon which research is organized, and even its extent in Great Britain, still compare unfavourably with that in some of its competitors, and it cannot yet be contended that with all the advances of the past twenty-five years the value of scientific research and its contribution to industrial progress or national welfare is generally appreciated either by the general public or by the Government.

The increased attention which is now being given to the general structure of the organization of research in Great Britain itself shows that the work of education has progressed. The twenty-five years' work of the Department will be considered not by itself but in relation to the research proceeding in industry, at the universities, and under more direct Government auspices, such as through the Agricultural Research Council or the Medical Research Council. If the expansion still required for the full service of the needs of individual industries or of national needs is to be secured, more than additional financial resources is required. There is still need for close co-ordination of exist. ing effort, and for the re-distribution of available resources, whether of personnel or equipment. The lack of proportion between scientific advance in different fields is a handicap which requires correction and involves further attention to our educational system, possibly by more fundamental methods than the distribution of grants to students or research workers. Progress here depends on the education both of public opinion and of the administrator. We may well hope that, in glancing over the twenty-five years' work of the Department of Scientific and Industrial Research, scientific workers may be led to take a further part in that task of education and give firmer and more united support to the elaboration of a national policy and programme of scientific and industrial research which will serve the nation's changing and growing needs, whether in peace or war, on a more adequate scale.

\section{SCIENCE IN THE ROYAL ACADEMY, I940}

\section{By Lieut. W. E. Swinton, R.N.V.R.}

$\mathrm{T}$ HE one hundred and seventy-second exhibition of the Royal Academy of Arts, which opened on May 6, is a typical "Royal Academy". That is to say, it is conservative and consists of the same kind of interesting, promising, or sometimes even satisfying works largely by the usual artists. Its subjects for the most part are retrospective, concerned with the personalities and events of the past rather than reflecting the tendencies and affairs of the present. It is therefore natural that the general tendency of the works is to portray the splendours of the seasons and those rural and coastal charms accessible to the country cottage rather than the stirring, if unpleasant, realities that confront us now. Artistic licence, however, like that of the poets, stipulates no adherence to the apparently stupendous events of the day, a fact which may explain why art is more enduring than the news-sheet.

There are, of course, a few works devoted to the more spectacular events of the last few months. Of these, pride of place goes to Norman Wilkinson's "River Plate Action", an inspiring representation based on the account given by Captain Woodhouse, R.N., and the same artist's "Air Battle, December 18th, 1939", painted from a description given by the leader of the formation. The Altmark incident is recalled by "The Stranded Prison-ship", by
Charles Gere, R.A. "The Convoy and her Guard", by A. J. W. Burgess; "Suburbia, 1939", by C. R. W. Nevinson, A.R.A.; and "Retribution", the end of a U-boat, by Arthur Burgess, bear testimony to the less spectacular necessities of these times.

So far as strictly scientific activities are concerned, this exhibition is no more lavish than its predecessors. If the highways and byways of scientific endeavour have any artistic stimuli, it must be admitted that the results do not pass the strait gate of Burlington House. Of the seventeen hundred works now shown, only about ninety can be said to be even incidentally of scientific interest, and that is taking both science and the subjects of the pictures at a very wide estimate.

As usual, the botanists and the geologists have nearly all the spoils, largely because flowers are amongst the most convenient themes for both indoor and outdoor painting, and because, on the other hand, landscape painters of even the most modern school can scarcely avoid some hint of the geological background.

Agriculture, as in last year's exhibition, has one of the best pictures of the year, by that habitual author of 'best pictures', Dame Laura Knight. It is entitled "January, 1940", and depicts a landgirl at work in wintry surroundings. 